\title{
Where are the Fish? Using a "Fish as Food" Framework to Explore the Thunder Bay Area Fisheries
}

\author{
Kristen Lowitt \\ Brandon University \\ Charles Z. Levkoe \\ Lakehead University \\ Connie Nelson \\ Lakehead University
}

\begin{abstract}
Thunder Bay is the largest city in Northwestern Ontario and is located on the northern shore of Lake Superior, the world's largest freshwater lake. While fishing and fish consumption are significant parts of the Thunder Bay area's food systems, the ability to purchase fish that are caught and processed in the region is extremely limited. While the lake once had an abundance of commercial fishing activity, today there are only a handful of commercial fishers left on the Canadian side and most of the catch is sold in the United States. In recent years, there have been growing efforts among community groups, local entrepreneurs, citizens, and Indigenous communities to enhance the sustainability of local food systems and ensure they can provide accessible, healthy, and culturally-appropriate foods, including fish.This article uses a "fish as food" framework to explore how policies and governance impact small-scale commercial fisheries in the Thunder Bay area's food systems. Based on twenty-five interviews with a diverse range of actors involved in fisheries, as well as a review of policies in the interrelated areas of fisheries management and food systems, we look at the barriers and potential opportunities for reintegrating small-scale commercial fisheries into food systems in the Thunder Bay area. Our findings indicate that fisheries governance is dominated by top-down approaches to resource management, to the detriment of equity, livelihoods, and access to local fish for consumption.
\end{abstract}




\section{Introduction}

Small-scale fisheries play a vital role in supporting food access and nutrition, as well as in maintaining traditional foodways and local economies for populations living in the world's rural and remote regions (Bell et al., 2015; Dey, Gosh, Valmonte-Santos, \& Rosegrant, 2016; Loring, Gerlach, \& Harrison, 2013). This is especially true in places where there is a historical and cultural connection to fishing and limited access to fresh vegetables and other domesticated meats (Islam and Berkes, 2016; Lowitt, 2013). This has been true for the Thunder Bay area, Northwestern Ontario's largest city, located on the north shore of Lake Superior. Lake Superior is the world's largest freshwater lake by surface area. and it is rich in biodiversity supporting over thirty native species of fish and many species of birds, amphibians, and mammals along its expansive coastline and on over 2,500 islands (Lake Superior Partnership, 2016; Minnesota Sea Grant, 2014).

Thunder Bay's population is about 110,000 and the city is a regional centre for social services, food, and other basic amenities for populations in more rural and remote areas of the region. European settlement in the area began in the late seventeenth century and the city became an important hub for forestry and some mining, along with transportation since grain is shipped through Thunder Bay's natural port from Western Canada. The majority of the settler population are of European and Scandinavian descent while Indigenous people make up almost $13 \%$ of the city's population, the highest proportion of urban Indigenous population in southern Canada (Statistics Canada, 2016). ${ }^{1}$ Many people are unable to access healthy and preferred foods, ${ }^{2}$ with new Canadians, lone-parent families, youth, Indigenous peoples, seniors, women, and racialized peoples particularly vulnerable (Thunder Bay and Area Food Strategy, 2015).

While fishing and fish consumption remain major elements of the Thunder Bay area's food systems (see Ontario Nature, 2014), locally caught fish are extremely difficult to purchase in the city now, especially in relation to other communities around Lake Superior in Canada and the United States (MacIver, 2016; Prinselaar, 2018). The lake once had an abundance of commercial fishing activity, yet in 2018 there were only three commercial fishing enterprises in the Thunder Bay area with most of the catch exported to markets in the United States. While there have 
been some efforts to consider the changing role of small-scale commercial fisheries in the Thunder Bay area's food systems (see for example Lowitt, Levkoe, Song, Hickey, \& Nelson, 2019a), government investments, research priorities, and civil society action have primarily focused on the agricultural sector. In this context, this article explores the barriers and opportunities for reintegrating small-scale commercial fisheries into food systems in the Thunder Bay area.

In recent years, there has been a growing focus, among non-profit organizations and entrepreneurs, on enhancing the sustainability of regional food systems and ensuring healthy and culturally-appropriate foods are available to the population. Here, fisheries have started to gain more attention. For example, the Thunder Bay and Area Food Strategy (2018) and Thunder Bay Food Charter (2008) identified the protection of Thunder Bay's watershed and the revitalization of its sustenance and commercial fisheries as vital to the region's food systems (see also, Ontario Nature, 2014). In addition, a number of local initiatives have taken significant steps to bring local commercially-caught fish back into the area's food systems through the establishment of locally owned businesses that reconnect harvesters and eaters (e.g., Eat the Fish, the Fish Shop, and Canadian Freshwater Fish), as well as through education, regional networking, and distribution (e.g., Cloverbelt Local Food Co-op and the Thunder Bay Country Market).

This study - of the barriers and opportunities for reintegrating smallscale commercial fisheries into food systems in the Thunder Bay area-is based on twenty-five key informant interviews in 2017 with fish harvesters, processors and retailers, First Nations and Tribal authorities, resource managers, and recreational fishers across the Lake Superior region of Canada and the United States. These interviews were semi-structured in format and they informed our understanding of the relationships between actors, policies, and governance relationships that influence Thunder Bay fisheries from a food systems perspective. Eight of the interviews were undertaken with informants involved in fisheries in the Thunder Bay area, through purposeful sampling that targeted leaders in sectors across food systems from harvesting and processing to distribution, marketing, and retail. Interviews focused on actors' roles in the fishery, their understanding of its governance dynamics, and their perspectives about how they fit into broader food systems. All interviews were audio-recorded, transcribed, and 
thematically analyzed using an inductive process of open coding (Berg, 2004). In addition to the interviews, we conducted a systematic review of relevant background information about fisheries and food systems, which included surveying provincial and federal government websites, communicating with experts, and reviewing the scholarly literature. The combination of key informant interviews and policy review provides an evidence base for understanding the current situation and the potential for small-scale commercial fisheries in the Thunder Bay area's food systems.

In what follows, we use a "fish as food" framework to explore the history of fisheries in the Thunder Bay area, and its relationship to food systems. We then analyze the contemporary policies and governance relationships surrounding Thunder Bay's small-scale commercial fisheries, ${ }^{3}$ paying attention to the key interrelated areas of harvesting, marketing/ consumption, and governance. Ultimately, we aim to contribute to a better understanding and action for building more equitable, healthy, and sustainable food systems in the Thunder Bay area, specifically concerning access to locally and sustainably caught fish.

\section{Fish as Food}

In this article, we use the analytical concept of food systems as a framework for approaching fisheries and fisheries governance. A food system can be described as the interconnected processes and infrastructures involved in feeding a population, including growing and/or harvesting food along with the processing, distribution, marketing, wholesaling, retailing, consumption, and waste management (Tansey and Worsley, 1995; Ericksen, 2008). A food systems framework can integrate a range of dimensions often addressed in isolation-for example, geographical, political, economic, policy, food security and nutrition, sustainability, and conviviality, among others (Feenstra, 2002). These dimensions can operate independently of each other, yet when they interact they have a profound impact on each other that shapes the way food systems function. As a framework, food systems direct us to consider a broader range of interconnections, their causes, and their outcomes.

Conceptualizing fisheries from a food systems perspective enables analysis of the interdependencies between aquatic and terrestrial ecosystems including outcomes for ecological and human health, food security, economically and culturally viable livelihoods, and community 
well-being based in principles of equity and democracy (see Levkoe, Lowitt, \& Nelson, 2017). We call this approach "fish as food." As Love, da Silva, Olson, Fry, \& Clay (2017) argue, food systems are an important part of the broader socio-ecological connections "integral to the viability and resilience of fishing businesses" and we need to understand fishing communities as part of this system rather than "simply the home of fishermen or a landing site for vessels" (p.12).

A fish as food framework assists in broadening the scope of smallscale fisheries by looking beyond the immediate fisheries actors (e.g., fish harvesters, resource authorities, fish stocks) to the broader and interdependent social, economic, and ecological relationships within which fisheries are embedded (Levkoe et al., 2017; Olson, Clay, \& da Silva, 2014). As Chuenpagdee (2018) explains, broadening the scope on small-scale fisheries is vital to moving beyond a dominant resourcist perspective that manages fish primarily as a commodity or natural resource for economic gain (see Berkes, 2010), to understanding the full range of values surrounding small-scale fisheries and their social, economic, and cultural contributions to fishing communities and regions.

At the same time, within the food systems literature fisheries receive relatively little attention as a focus on agriculture and terrestrial-based forms of food production dominates research (Levkoe et al., 2017; Nelson et al., 2013). For example, as Seto \& Fiorella (2017) argue, "Resources that originate in our oceans, rivers, and lakes are almost entirely omitted in our conceptions of a sustainable food system." They attribute this to fragmented notions of food resources that fail to see fisheries and agriculture as interlinked. Fisher et al. (2017) similarly found that fisheries are rarely considered in analyses of global food systems and as a result are underrepresented in major food security policy and programming initiatives. A fish as food framework can help address this gap in food systems research and policy.

To operationalize our fish as food framework, we identify three analytical elements that collectively broaden the scope of the ways that fisheries are typically studied and that help better understand fisheries in the Thunder Bay area. These elements are fish harvesting, the fisheries value chain, and governance and decision-making.

First, fish harvesting focuses on aspects that are typically considered within fisheries management. Management responsibilities include fish 
population assessments, fish stocking, habitat restoration and design, and enforcement of harvesting regulations, including licensing (Song, Temby, , Krantzberg, \& Hickey, 2017). Fisheries management in Lake Superior is primarily organized through centrally coordinated, top-down government structures (see Mahon et al., 2008), and, as we argue below, are resourcist in outlook.

The second element of our framework extends the analysis beyond harvesting and management to consider the range of actors and policies impacting fisheries along the entire value chain from harvesting to distribution and marketing to consumption, and how these activities interact to shape fisheries livelihoods and ecosystems. Here, we consider the social and cultural as well as economic values in which fisheries are embedded across the value chain (see Lowitt et al., 2019a).

The third analytical element is governance and decision making. This element addresses the power relationships among actors across the entire value chain, including fish harvesting as well as actors that typically fall beyond a resourcist management perspective including civil society and the relationships among settler governments and First Nation authorities.

\section{Thunder Bay Area Fisheries: An Historical Context}

Fisheries in the Thunder Bay area have significant historical and cultural value. The history of the area is closely tied to the development of fisheries, which have undergone tremendous changes throughout the last several centuries. For millennia, Anishinaabe peoples made use of Lake Superior's abundant wildlife and fishing (Quimby, 1960; Rogers,1972; Hansen, 1986), with fish as a regular food source and deeply integrated into cultural and spiritual practices (Bogue, 2000; Lemelin et al., 2014). Small groups united by ties of kinship followed a mobile lifestyle during the winter season with larger communities gathering at their preferred fishing locations during spring and summer (Dawson, 1983) where intertribal trading could occur (McCullough, 1989). Fishing was based on an integrative form of governance that ensured survival and which formed the basis of identities and cultures tied to land and water ecosystems (Coulthard, 2014).

Indigenous fishing activities were disrupted with the arrival of European settlers in the early seventeenth century to exploit a lucrative fur trade. Throughout the seventeenth and into the late nineteenth centuries, commercial fishing helped to support the fur trade and Indigenous people 
were central in the harvesting, packing, and curing of fish (Fort William First Nation, 2018). When the fur trade collapsed in the late nineteenth century, many traditional practices had been abandoned and Indigenous peoples were inundated with new agents of change, including the push to organize into treaty groups (Dawson, 1983). For example, after the signing of the 1850 Robinson Treaties, which cover most Anishinaabe settlements in the Thunder Bay and Lake Superior area, policy shifted. While the treaties proclaimed the privilege of hunting and fishing as they have "heretofore been in the habit of doing" (see Indigenous and Northern Affairs Canada, 2010), the government often interpreted this to mean that fishing was allowed only if it was for consumption (see Parliament of Canada, 1997), thus marginalizing Indigenous people from the local fishing economy.

Beginning in the late nineteenth century, an influx of Finnish and Swedish people brought their skills, knowledge, and interest in commercial fishing to Lake Superior (Roinila, 2003). The Thunder Bay area fishing stations (e.g., wharves, flakes for drying fish) were located at Rossport, Sibley Peninsula (Johnson Landing, Pass Lake), and Hurkett (Roinila, 2003) (Figure 1). In the off-season, most of the commercial fishers established a base in Thunder Bay. Fish was an important food source for local households, with smoked, pickled, canned, or salted varieties consumed during the winter months (Swedish Finn Historical Society, 2009). After the establishment of the railway in the early twentieth century, some of this fresh fish was shipped by train to distant North American markets (Goodier, 1982).

In the late nineteenth century, fisheries also began changing substantially through the introduction of modern fisheries management. This involved the institutionalization of a resourcist perspective on fisheries that centralized power and authority with the state. The further concentration of power led to the rise of a managerial class that sought to manage both people and fish for maximum efficiency and economic return, and prioritized positivist science over other forms of knowledge (Berkes, 2010; Bavington, 2010). In 1857, the Fisheries Act (Province of Canada) was passed and it required the appointment of overseers to enforce new regulations; this created hostility with many fishers who resented this new outside authority (OMNRF, 2012-2018a). This Act was also applied to Indigenous peoples "equally" with other members of the public, 
representing a further diminution of Indigenous rights (Blair, 19961997; Koenig, 2005). In 1868, during the first session of the new federal parliament, the federal Fisheries Act was passed, assimilating provincial laws and establishing the federal Department of Marine and Fisheries (known today as the Department of Fisheries and Oceans). Federal and provincial governments began vying for control of commercial and sport fisheries, with jurisdiction eventually ceded to the province of Ontario (OMNRF, 2012-2018a). This delegation of responsibility continues to this day with the Ontario Ministry of Natural Resources and Forestry (OMNRF) having authority for fisheries management in inland waters under the Ontario Fishery Regulations annexed to the federal Fisheries Act.

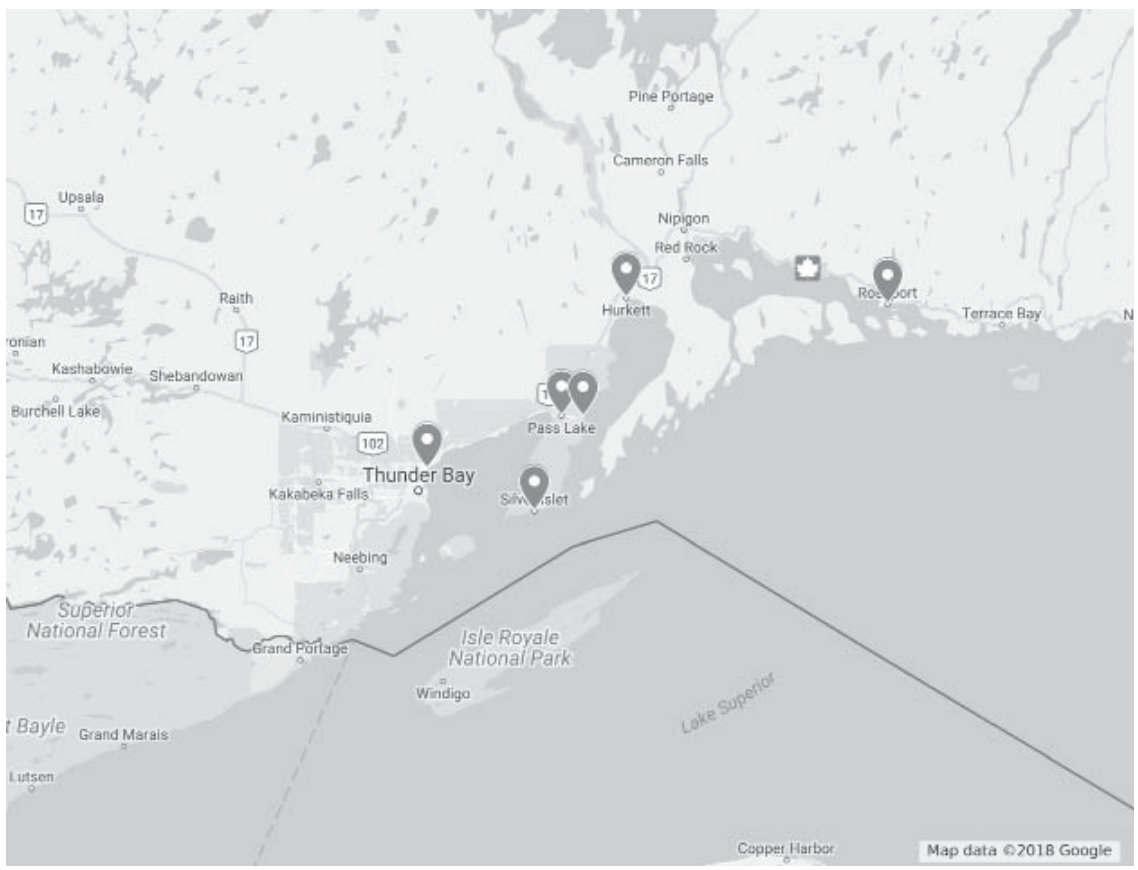

Figure I.Thunder Bay area fishing stations (Source Google Maps, 2018) 
By the early twentieth century, the ecological well-being of the Lake Superior watershed was impacted by many competing macroeconomic activities, including mining and tailings, dams to power forest company operations, and commercial trade along the Great Lakes-St. Lawrence Basin. During the Second World War, increasing pressure was also placed on Lake Superior fish stocks to provide for food needs during the war, with large quantities of fish exported out of the area. In the 1940s, fish stocks already vulnerable from overexploitation and pollution were further ravaged by the invasive sea lamprey that feed on the blood of lake-dwelling fish. In the following decades, the province managed declining catches by limiting commercial fisheries operations and by creating fishing zones for fish harvesters that were often in deeper water where less fish thrived. Over time, this led to a decrease in the number of commercial fishing enterprises and the disappearance of many small fishing communities and fish processing facilities (Wightman \&Wightman, 1997).

In addition to state-led fisheries management authorities, transnational bodies were established over time. The first bi-national body was the International Joint Commission (IJC), formed under the Boundary Waters Treaty Act (1909) to deal with issues of water quality and to resolve disputes in transboundary waters. In 1955, the Great Lakes Fishery Commission (GLFC) was established to control the sea lamprey. The GLFC had considerable success in managing sea lamprey through various technological means and continues to facilitate fisheries research and management planning across state, provincial, and federal agencies. While important to fostering co-operation, these bodies have also been critiqued for being overly bureaucratic and for not understanding the complexity of social-ecological relationships around the Lake (Henquinet \& Dobson, 2006; Krantzberg \& Manno, 2010).

Since the 1980s, fish populations in Lake Superior have begun to recover largely due to government-led efforts to enhance water quality and control invasive species. Although far from historic levels, Lake Superior is the only Great Lake with a self-sustaining lake trout population (Spooner, 2014). Lake whitefish has also recovered with OMNRF indicating stable populations especially in the western part of the lake near Thunder Bay. Lake herring supports a fairly large fall fishery and is particularly valuable for its roe (eggs). However, OMNRF indicated that today there are only three commercial fish harvesters in the Thunder Bay area, with 
the majority of catches exported to the United States. Tourism and sport fishing have also emerged as a policy priority for the OMNRF over the past several decades as sport fishing (and the associated fishing charters, accommodations, and so on) have become part of a burgeoning economic industry with considerable political power (see Crawford, 2001; Liuson, 1997). This is a factor potentially constraining the interest and resources that the ministry has put towards the commercial sector.

Lastly, of significance to the viability of a fishing sector that can support access to local fish are Indigenous communities around Lake Superior and the Great Lakes region more broadly that are increasingly asserting their existing Aboriginal and treaty rights to fish, including commercially. Around Lake Superior and the Great Lakes region there are different types of governance arrangements in place between First Nations and the provincial and federal governments with regards to commercial fishing. There are several First Nations in proximity to Thunder Bay with varying degrees of fishing activity. Fort William First Nation, located just outside the city of Thunder Bay, had several families that fished commercially for much of the twentieth century (Fort William First Nation, 2019); according to our interviews, no one in the community is presently fishing on Lake Superior, but there are indications they may be seeking to reestablish their fishery. Red Rock Indian Band located east of Thunder Bay has a commercial fishery on Lake Nipigon, a large inland lake within the Lake Superior watershed. In the next section, we touch on these considerations related to the development of Indigenous fisheries along with the barriers and potential opportunities for reintegrating small-scale commercial fisheries into food systems around Thunder Bay.

\section{Barriers and Opportunities for Thunder Bay Fisheries}

In this section we explore contemporary fisheries in the Thunder Bay area through the three elements of a fish as food framework: fish harvesting, broadening the fisheries value chain, and governance opportunities. Drawing on our interviews with fisheries actors across the Lake Superior region, background information, and a review of relevant policy documents, we address each of these elements in turn. 


\section{Fish Harvesting}

The management of Thunder Bay's commercial fisheries is guided by the Strategic Policy for Ontario's Commercial Fisheries (see OMNRF, 2011). Through this document, the OMNRF identifies key policy priorities for the province's commercial fisheries, within the legislative framework set out in the Ontario Fishery Regulations (2007). While the strategy names ecological sustainability and inclusivity as important principles, we suggest that, in practice, management continues to be rooted primarily in a resourcist view that treats fish as a commodity for economic gain and doesn't adequately support local participation and inclusion of local knowledge, especially in the Thunder Bay area.

A key shift in fisheries management occurred in the early 1980s when the province pursued a policy of modernizing commercial fisheries. An important outcome was the adoption of Individual Transferable Quotas (ITQ. ITQs are a market-based allocation that enable fisheries managers to allocate pre-determined shares of the Total Allowable Catch (TAC) to individual fish harvesters, and fish harvesters to transfer them to others (McKay et al., 1995). ITQs have become a popular management tool across the world to apply a quasi-private property rights regime to fisheries. ${ }^{4}$ In Ontario, amounts are determined based on scientific data collected by government bodies. Licence holders must also be Canadian citizens and a quota can only be leased to another licence holder within the same management zone. ${ }^{5}$

Despite these restrictions, ITQs encourage licence holders to treat fish as a tradable commodity. A fish harvester we spoke with postulated that a fish processing company from the United States had obtained quota and then secured arrangements with Thunder Bay area fish harvesters to fish for the company. He explained, "they [the US fish processor] don't have a boat here. They don't have a crew here. So they say okay I'll give you [Thunder Bay fish harvesters] ten thousand pounds of whitefish, you get ten, you get ten. So now that's like a ten thousand dollar raise for you if you can catch them and there's a market for them to go to." In Ontario, quota must be held by a Canadian licence holder. In our discussions with government officials, it is likely that an American company is financially supporting a Canadian licence holder to set up a subsidiary Ontario-based business to lease quota and in so doing is securing their access to fish. As explained in the quote above, this Ontario business isn't fishing but secures 
relationships with other harvesters to catch fish that serves the US market. As a result, the ITQ system facilitates this as a legitimate relationship.

Some have promoted ITQs as an effective management tool for enabling the most efficient harvesters to fish and encourage stewardship over the fishery (McKay, 1995). However, ITQs have also been criticized for providing exclusive access to a public resource and contributing to a concentration of wealth in the fishery (Pinkerton, 2013). From a fish as food perspective, this raises concern that fish will flow towards wherever the most capital resides. Our interview findings indicate that this is likely occurring around Thunder Bay, with most fish caught in the area shipped to fish markets in Boston and Chicago and sold as low-quality protein to be processed into gefilte fish (a dish made from a poached mixture of ground and deboned fish). This not only minimizes local access to fresh fish, it also distances fish harvesters from consumers, and integrates harvesters into long-distance supply chains in which they have relatively little control over prices and most often no contracts. These food systems interdependencies are generally overlooked within management, and we discuss them in more detail in the following section.

ITQs are only one specific example of a resourist approach to the harvesting of fish that emerged in our research. It is important to note that ITQs, and the export of fish they may encourage, is the most recent manifestation of a longer trend, with fish being shipped out of the region in long-distance supply chains since the nineteenth century. This resourcist view has deep roots in Canada's political economy as explained in Harold Innis's (1967) staples thesis. ${ }^{6}$

Another concern that emerged in our study, related to the harvesting and management of fish, was a lack of consideration of fish harvesters' local knowledge. The Strategic Policy for Ontario's Commercial Fisheries (2011) suggests that management should account for sources of local and traditional knowledge in fisheries. Nonetheless, a fish harvester we spoke with claimed, "The biologists ... people with degrees figure that everybody else is down below them ... When you say look this is [happening], what do you know about it? I've got a degree in biology. Well you don't make your living off of it." Likewise, an OMNRF employee explained, "We always just go with the best available science ... this stuff [local knowledge] is in my head rattling around but when I make decisions I still can only point to that point on the graph." Recognizing fish harvesters' local knowledge 
is important to empowering harvesters within decision-making processes, increasing capacity to manage fisheries sustainably (see Haggan, Neis, \& Baird, 2007) and supporting the different knowledge systems important to sustainable food systems (Levkoe et al., 2017).

Lastly, there are significant gaps pertaining to the participation of First Nations within management. For example, no First Nation in the Great Lakes region has official standing within the Great Lakes Fishery Commission. The Saugeen Ojibway Nation on Lake Huron argues there is evidence to indicate First Nations were intentionally excluded from participation in the Commission (see Saugeen Ojibway Nation Territories, 2004). The IJC, which doesn't focus specifically on fisheries management but more broadly on water quality, has similarly been critiqued for treating First Nations as stakeholders and not recognizing the full extent of their Aboriginal and treaty rights (Norman, 2015).

\section{Broadening the Fisheries Value Chain}

From a fish as food perspective, considering the harvesting and management context of fisheries and how this intersects with subsequent parts of the entire value chain is critical. Our policy review indicates that management authorities tend to focus on fish only up to the point of harvesting, ignoring what happens to fish after they are landed and the range of individuals and groups that play a role in the fisheries, from lake to plate and beyond (see also Love et al., 2017). After harvest, other authorities take over resulting in a siloed approach with various government offices often working in isolation.

From a fish as food perspective, there are many different fisheries management policies that refer to food but also which limit the scope of fisheries. For example, the Strategic Policy for Ontario's Commercial Fisheries identifies a wholesome food source as a social benefit of commercial fisheries. Similarly, transnational agreements, such as the Joint Strategy Plan for the Management of Great Lake Fisheries (facilitated by the GLFC) and the Great Lakes Water Quality Agreement (facilitated by the IJC), recognize that fisheries are an important source of food with the latter particularly concerned with pollution in this context. Many of these policies also emphasize sustainable fisheries, in terms of ensuring that Lake Superior fisheries are sufficiently protected such that future generations may enjoy them. However, while these policies make some reference to 
fish as a food source, a food systems perspective is lacking. That is, these policies do not view fisheries as a part of food systems but rather as a natural resource that, if managed and protected well, may provide some benefits as a food source. Other aspects of fish as food, such as safety, processing, quality, nutrition, and consumption are located in various provincial and federal ministries of health, food, and agriculture. As evidence of this lack of a food systems perspective, a local fish harvester expressed frustration that, "they [OMNRF] classify us as a user group. We're not a user group, I hate that term. We're supplying food for the population of this province that doesn't angle [fish]."

Despite this lack of a systems perspective, harvesting and management regulations affect subsequent stages of the fisheries value chain, such as how much and what types of fish are available for processing and consumption, and who is catching it and how. The relationship among ITQs and the flow of fish into the US markets is just one example of this interconnection. More broadly, over time, as the province has sought to make the fishery more efficient through encouraging a reduction in the number of fish harvesters, this has been accompanied by a reduction and consolidation among the fish buyers and processors.

Thunder Bay fish harvesters have come to rely on few buyersgenerally from outside the area-to procure their catch. While some fish stays in Ontario, much of this catch is sent to large markets in the United States. A cost-price squeeze and a lack of contracts with these companies makes harvesters vulnerable to low and fluctuating prices. Because of concentration in the industry, smaller processors are also being squeezed. A fish processor from the eastern Lake Superior region summarized the situation:

The cost of what that processor or producer gets hasn't increased with the cost of living by any stretch. I mean, the price of lake trout that the fishermen get right now, I got that much or more 40 years ago and yet the cost of fuel on boats skyrocketed 10 times. A lot of the guys are in it because it's what they loved doing all their life and that's what they've done .... Some have branched out a little bit and started doing some of the value-added stuff, local trades which increases their overall income. 
Concerns about regular access to markets and fair prices that emerged in our study are consistent with other recent research indicating these are top concerns for freshwater fishers in other parts of the country (Fisheries and Oceans Canada, 2017). Across Canada and in the Thunder Bay area, alternative marketing arrangements for fisheries are emerging in response, such as fish markets, fisheries co-operatives, and community supported fisheries (DesRivieres, Chuenpagdee, \& Matheret, 2017). While these marketing arrangements seek to address some of the vulnerabilities harvesters face in the long-distance supply chain, these are also based on broader sets of values such as reconnecting harvesters and eaters, supporting ecological sustainability, and building a renewed relationship with the lake.

Succession planning for fisheries enterprises in the region is also a key concern. This was recognized by an OMNRF resource manager who said, "Fishing is super hard work and ... You can't find people in Ontario who are willing to do that work anymore. It's hard. If you're talking about Lake Superior, our fishers are not young. None of them. Smith [not real name] has his sons working with him, he might take over the business. Other guys, they don't have anybody who is going to fill their shoes." Compounding this challenge is the reality that no new commercial fishing licences are being issued by the province and existing licences are quite expensive to purchase. However, licences can be transferred intergenerationally without paying the sale value.

Presently, succession planning is not on the radar of provincial fisheries policy but may be key to revaluing fishers not just as resource harvesters but as local food providers with important intergenerational knowledge about the local ecosystems and relationships with communities.

\section{Governance and Opportunities}

Lastly, integral to the consideration of a fish as food framework are dynamics in governance and decision-making. In the above subsections we have identified some governance challenges for Thunder Bay area fisheries when considering the broader fish as food framework, including limited power in decision making for fish harvesters, insufficient Nation to Nation relationships in fisheries management, and a siloed approach to policy that separates fish harvesting from other aspects of food systems. In addition to these concerns, a civil society leader we spoke with was concerned about a lack of grassroots engagement in fisheries governance, and through their 
work "trying to re-center not just governments or big NGOs voices" but citizens' voices.

The presence of a civil society voice was further weakened by budget cuts that led to the 2015 closure of the Lake Superior Binational Forum (LSBF), the only basin-wide citizen stakeholder forum that ran for nearly twenty-five years. Recent research has attested to the central importance of civic engagement and community advocacy to the future resilience of the ecology and society of the lake (Langston, 2017). Overall, we suggest that top-down approaches and a resourcist view tends to dominate in fisheries governance to the potential detriment of equity, local livelihoods, and access to local fish for purchase in an area in which it is a culturallyappropriate and nutritious source of food. This doesn't mean there isn't a role for the state; rather, this research supports the need for a shift towards more inclusive and participatory governance of fisheries (see Jentoft et al., 2010; Song, Chuenpagdee, \& Jentoft, 2013).

Thinking critically about governance presents opportunities for configurations of decision-making and engagement. Recognizing the challenges described above, individuals and organizations working to improve the ecological and social health of Lake Superior have claimed that there is a need for different kinds of decision-making structures as well as a shift in the power relationships that govern the watershed. One non-profit worker we spoke with argued that problems could not be solved by governments since they were the ones that created the problems (i.e., through legislation) in the first place: "For me there's very little legitimacy in the International Joint Commission or the Ministry of the Environments or in stakeholder conservation authority type things. These are shadows of what we could have when it comes to great lakes governance." Instead, he suggested there was a need to create new forms of leadership based on a different kind of governance emerging out of a relational ethics: "[The] idea that we are in relationship with all of those upstream and downstream." For example, he noted that prior to the arrival of Europeans, the waters of Lake Superior were shared between various Indigenous nations. This approach to governance is based on a set of social agreements rooted in equity and sustainability. In respect to fisheries, he argued that "fish are not just a resource. They are part of a system, a way of knowing and a way of being human." This kind of governance is illustrated through the Great Lakes Commons Map (https://www.greatlakescommons.org/commons- 
map/), an open source platform for place-based digital storytelling. The map is a tool that collects and shares diverse place-based experiences in order to create a democratic knowledge commons.

Two locally-owned businesses, Eat the Fish and Canadian Freshwater Fish, are also promising examples of new types of governance arrangements that are pushing beyond values of economic gain to think about how economic development can be done in ways that support local livelihoods, ecological sustainability, and access to nutritious food. The newlyestablished local fish processor in Thunder Bay, Canadian Freshwater Fish, is trying to support a new generation of younger people to enter fishing by providing greater livelihood security for fish harvesters. They explained:

We're hoping, because now they're [fish harvesters] going to have a local place they can sell to and they're not going to have to wait for Boston [American fish buyer] to come here twice a week or whatever it is, they can sell their stuff every day and make a really good living off of it, we're hoping that some of the younger guys will start getting into it. That is what we're hoping ... We want the fishermen to be able to make a living off of it. We talked about it last time. A lot of the fishermen here and in the communities, are older. It's an older generation and the younger generation hasn't taken up and gotten into it; that's a concern for us because if these older fishermen stop doing it and then there's nobody to fill that void, then that's a big problem.

Similarly, Eat the Fish, a small independently owned business founded in Thunder Bay in 2016, is experimenting with innovative ways to source and market locally caught and wild fish. The two co-founders recognized there were few opportunities to purchase local fish in the region commenting that, prior to starting Eat the Fish, most people "had no idea that there was even a [commercial] fishing industry here." Each week, Eat the Fish sets up a fish stand at the Thunder Bay Country Market, offering a direct-to-customer model that provides fish harvesters a better per-pound price while ensuring that fish caught in the region are kept in the Thunder Bay area. They also seek to provide customers with a closer connection to fish harvesters and to the lake. As one of the co-founders explained, "we're trying to share their [fish harvesters] stories ... because 
we think it's important for people to take some pride in what we have here." While Eat the Fish sells popular commercial species like Lake Whitefish, they have also helped to establish new local markets for underutilized native fish species such as burbot - typically a bycatch for fish harvesters due to low market demand. By offering market-goers education and taste samples about native fish species that have typically been less popular as an eating choice, they have created another revenue stream for fish harvesters while also reducing waste in the form of bycatch. In this way, Eat the Fish is a promising example of working across the fisheries value chain to align fisheries harvesting/management with human health and consumption goals.

Finally, processes of governance are being questioned by some Indigenous communities on Lake Superior, both in terms of the epistemological underpinnings of resourcist management approaches and with regards to the underlying authority of the Crown and the province to manage fisheries. Some First Nations have begun to actively assert their own systems of governance, based on different ways of knowing, and interrelationships and reciprocity among people, fish, and ecosystems. As such, Indigenous fisheries are emerging that look different from those managed by the province of Ontario. Batchewana First Nation (BFN) in eastern Lake Superior is one example of a commercial fishery that the community is managing in alignment with their traditional knowledge, oral teachings, and inherent responsibilities (see Lowitt, Levkoe, Lauzon, Ryan, \& Sayers, 2019b). With one of the largest fisheries on the Canadian side of Lake Superior, BFN currently has twenty-seven active captains. Fish are an important part of the community's diet and livelihood with much of the catch sold to local processing plants, local restaurants, and retail outlets in the neighbouring city of Sault Ste. Marie. Chief Dean Sayers described this as a system of governance that works with nature and is driven by the intergenerational transfer of knowledge built over time between the people and their relationships to the natural environment. Those First Nations in greater proximity to Thunder Bay, including Fort William, Red Rock, and Michipicoten, are also engaged in efforts to reestablish their commercial fisheries, which could influence the nature of commercial fisheries in the area, including the scope and orientation of management, along with the availability of fish for purchase within the Thunder Bay area. ${ }^{7}$ 


\section{Conclusion}

Ultimately, fisheries governance, whether implicitly or explicitly, is guided by a series of underlying values and ethics (Wiber, Berkes, Charles, \& Kearney, 2004). As Ommer \& Paterson (2014) write, "Management objectives are, or should be, a reflection of what we value in a fishery, such as a healthy ecosystem that supports healthy fish stocks, vibrant fishing communities, and a healthy fishing economy." As Song, Chunepagdee, \& Jentoft (2013) point out, the expression of values is also tied to power relations, as there is a risk that the values and principles of some may dominate, suppressing those of others. From a fish as food perspective, our research suggests that being upfront about these values, power dynamics, and ethics is a fundamental part of the complexity surrounding fisheries.

Fisheries management policies remain generally focused on a narrow set of values that, while sometimes acknowledging food, are missing a broader food systems perspective. This disconnect between food systems and fisheries management is not unique to the Thunder Bay area and has been widely observed in the literature. In this article, using a fish as food framework we have sought to identify some of the key governance and policy factors shaping the availability of local fish for purchase in the Thunder Bay area. We hope that this article may spur further conversation about the role of fisheries in the Thunder Bay area's food systems and contribute to emerging efforts (such as seen in the Thunder Bay and Area Food Strategy) to support a sustainable and equitable freshwater foods economy for the area.

Future research could explore additional empirical data through a broader population sample of food systems actors beyond the Thunder Bay area. Interrogating the broader fisheries relationships across the Lake Superior watershed can point to solutions that address the barriers of more equitable and sustainable fisheries. This research should also ask: How can collective rights and responsibilities surrounding fisheries and the lake be balanced with individual rights? Can a local food system for fish succeed given existing values, and how might thinking about food systems contribute to a reconceptualization of the values surrounding fisheries? We agree with Song et al. (2013) that governance challenges could be lessened if "values, images, and principles are made explicit, understood, and articulated in the policy and decision-making process" (167). 


\section{Notes}

1. This population statistic is likely a conservative estimate since the Census tends to under-count Indigenous people due to poverty and associated factors such as no fixed address, distrust of government, and migration between geographical locations (Rotondi et al., 2017).

2. It is estimated that approximately $10 \%$ of Thunder Bay's population age twelve years and older experiences moderate to severe food insecurity (Statistics Canada, 2018).

3. Thunder Bay's commercial fisheries have the attributes of being small-scale, including targeting multiple species and being carried out by individuals or families (Aguilera et al., 2015).

4. As McKay (1995) et al. explain, depending on how the particular ITQ system is designed, harvesters can buy, sell, lease, trade, and inherit shares, almost just as they would any other property. In Ontario commercial fisheries, ITQs can be leased between licence holders. This is close to what is usually thought of as private property. However, unlike private property rights to land, the government retains the right to determine an overall quota and other aspects of the fishery that affect sustainable use of the fish stocks. Thus, ITQs may be defined as quasi-private property.

5. The Government of Ontario has divided the province into twenty fisheries management zones (FMZs) to ensure management is based on the specific needs and characteristics of different areas. Regulations can be customized to each zone (e.g., conservation efforts, catch limits, and fishing seasons) (see Government of Ontario n.d.), with advisory councils set up in each zone to hear from stakeholders.

6. In the staples thesis, Innis argued that Canada's political and economic development was deeply tied to the search and exploitation of its staples commodities for export to more advanced economies.

7. Ontario's first priority in fisheries allocation is to conservation. After conservation, Aboriginal and treaty rights to fish for food, social and ceremonial purposes take priority. In the case of existing Aboriginal commercial fishing rights, OMNRF allocates fisheries resources in accordance with its understanding of case law. Remaining fish are allocated to recreational, (non-Indigenous) commercial, and bait fisheries (OMNRF 2012-2018b). 


\section{References}

Aguilera, S.E. et al.. (2015). Managing small-scale commercial fisheries for adaptive capacity: Insights from dynamic social-ecological drivers of change in Monterey Bay. PLoS ONE, 10(3). https://doi.org/10.1371/journal. pone.0118992

Bavington, D. (2010). Managed annibilation: An unnatural bistory of the Nerwfoundland cod collapse. Vancouver, BC: UBC Press.

Bell, J. et al. (2015). Optimising the use of nearshore fish aggregating devices for food security in the Pacific Islands. Marine Policy, 56, 98-105. http://doi. org/10.1016/j.marpol.2015.02.010

Berkes, F. (2010). Shifting perspectives on resource management: Resilience and the reconceptualization of 'natural resources' and 'management.' MAST, 9(1), $13-40$.

Berg, B. (2004). Qualitative research methods for the social sciences (5th edition). Boston MA: Pearson Education Inc.

Blair, P. (1996). Solemn promises and solum rights: The Saugeen Ojibway fishing grounds and R. v. Jones and Nadjiwon. Ottawa Law Revierw, 28, 125-143.

Bogue, M. B. (2000). Fishing the Great Lakes: An environmental history, 1783-1933. Madison: University of Wisconsin Press.

Blay-Palmer, A. (2008). Food fears: From industrial to sustainable food systems. Aldershot and Burlington: Ashgate Publishing, Ltd.

Blay-Palmer, A. (Ed). (2016). Imagining Sustainable Food Systems (pp. 15-28). London: Routledge.

Chuenpagdee, R. (2018). Innovations in small-scale fisheries: Contributions from the research community. TBTI Global Partnership for Small-scale Fisheries Research. Retrieved from https://scfworkshop.sciencesconf.org/data/Ratana talk Brest SSF.pdf

Coulthard, G. (2014). Red skins, white masks: Rejecting the colonial politics of recognition. Minneapolis: University of Minnesota Press.

Crawford, S. (2001). Salmonine introductions to the Laurentian Great Lakes: A historical review and evaluation of ecological effects. In Canadian Special Publication of Fisheries and Aquatic Sciences No. 132. Ottawa: NRC Research Press.

Crouch, M., \& McKeniz, H. (2006). The logic of small samples in interview-based qualitative research. Social Science Information, 45(4), 483-499. 
Dawson, K.C.A. (1983). Prehistory of the interior forest of Northern Ontario. In A.T. Steegmann,Jr. (Ed.), Boreal forest adaptations: The northern algonkians (pp 55-84). New York: Plenum Press.

DesRivieres, P., Chuenpagdee, R., \& Mather, C. (2017). Reconnecting people, place, and nature: Examining alternative food networks in Newfoundland's fisheries. Agriculture and Food Security, 6, 33. https://doi.org/10.1186/ $\underline{\mathrm{s} 40066-017-0112-\mathrm{x}}$

Dey, M., Gosh, K., Valmonte-Santos, R., \& Rosegrant, M. (2016). Economic impact of climate change and climate change adaptation strategies for fisheries sector in Solomon Islands: Implication for food security. Marine Policy, 67, 171-178. https://doi.org/10.1016/j.marpol.2016.01.004

Environmental Commission of Ontario. (2011). Engaging solutions annual report 2010/11. Retrieved from http://docs.assets.eco.on.ca/reports/environmentalprotection/2010-2011/2010-11-AR.pdf

Ericksen, P. J. (2008). Conceptualizing food systems for global environmental change research. Global environmental change, 18(1), 234-245.

Feenstra, G. (2002). Creating space for sustainable food systems: Lessons from the field. Agriculture and Human Values, 19(2), 99-106.

Fisher, B. et al. (2017). Integrating fisheries and agricultural programs for food security. Agriculture E Food Security, 6, 1. https://doi.org/10.1186/ s40066-016-0078-0

Fisheries and Oceans Canada. (2017). Engagement Report, November 2017. Retrieved from http://www.dfo-mpo.gc.ca/fm-gp/peches-fisheries/comm/ ffmc-cpea/FFMC-engagement-CPEA-eng.htm

Fort William First Nation. (2019). Aboriginal consultation and accommodation. Retrieved from https://fwfn.com/traditional-territory-the-duty-to-consult/

Goodier, B. (1982). The fish and fisheries of Canadian Lake Superior. Toronto: Institute for Environmental Studies, University of Toronto.

Government of Ontario. (n.d.). Fisheries management zones. Retrieved from https://www.ontario.ca/page/fisheries-management-zones

Hansen, L.C. 1986. Historical report of Indian fishing in Ontario. Indian Resource Policy. Toronto: Ontario Ministry of Natural Resources.

Henquinet, J., \& Dobson, T. (2006). The public trust doctrine and sustainable ecosystems: A Great Lakes Fisheries case study. Nerw York University Environmental Law Journal, 14(2), 322-373. 
Innis, H. A. (1967). The importance of staple products. In W.T. Easterbrook and M.H. Watkins (Eds.), Approaches to Canadian Economic History. Toronto: McClelland and Stewart.

Indigenous and Northern Affairs Canada. (2010). Robinson-Huron and Robinson-Superior Treaties. Retrieved from https://www.aadnc-aandc.gc.ca/ eng $/ 1100100028970 / 1100100028972$

Islam, D., \& Berkes, F. (2016). Indigenous peoples' fisheries and food security: A case from northern Canada. Food Security, 8(4), 815-826. https://doi. org/10.1007/s12571-016-0594-6

Jentoft, S., Chuenpagdee, R., Bundy, A., \& Mahon, R. (2010). Pyramids and roses: Alternative images for the governance of fisheries systems. Marine Policy, 34(6), 1315-1321.

Knezevic, I., Blay-Palmer, A., Levkoe, C.Z., Mount, P., \& Nelson, E. (Eds). (2017). Nourishing communities: From fractured food systems to transformative pathways. Springer International. https://doi.org/10.1007/978-3-319-57000-6

Koenig, E. (2005). Cultures and Ecologies: A native fishing conflict on the SaugeenBruce Peninsula. Toronto: University of Toronto Press.

Krantzberg, G., \& Manno,J.P. (2010). Renovation and innovation: It's time for the Great Lakes regime to respond. Water Resources Management, 24, 4273-4285.

Lake Superior Lakewide Action and Management Plan 2015-2019. (2016). The Lake Superior partnership. Retrieved from https://binational.net/wpcontent/uploads/2016/09/Lake\%20Superior\%20LAMP\%202015-2019.pdf

Langston, N. (2017). Sustainable Lake Superior. New Haven: Yale University Press.

Lemelin, H., Dampier, J. E., Makin, D., \& Cross, J. (2014). Aboriginal erasure or aboriginal historical exclusion? Using video interviews to recognize the role of aboriginal peoples on Kitchi-Gami (Lake Superior). Journal of Rural and Community Development, 9(3). https://journals.brandonu.ca/jrcd/article/ view/808

Levkoe, C., Lowitt, K., \& Nelson, C. (2017). “Fish as food”: Exploring a food sovereignty approach to small-scale fisheries. Marine Policy, 85, 65-70. https://doi.org/10.1016/j.marpol.2017.08.018

Liuson, E. (1997). The allocation of commercial fishing rights within the Great Lakes. Environment Probe. Retrieved from https://environment.probeinternational.org/1997/06/30/ the-allocation-of-commercial-fishing-rights-within-the-great-lakes/ 
Loring, P.A., Gerlach S.C., \& Harrison H. (2013). Seafood as local food: Food security and locally caught seafood on Alaska's Kenai Peninsula. Journal of Agriculture, Food Systems, and Community Development, 3(3). https://doi. org/10.5304/jafscd.2013.033.006

Love,D., da Silva,P.,Olson,J.,Fry,J.,\& Clay,P.(2017).Fisheries, food, and health in the USA: The importance of aligning fisheries and health policies. Agriculture and Food Security 6(16). https://doi.org/10.1186/s40066-017-0093-9

Lowitt, K., Levkoe, C., Song, A., Hickey, G., \& Nelson, C. (2019a). Broadening the scope: Fisheries and place-based food systems in the Lake Superior region. In R. Chuenpagdee \& S. Jentoft (Eds.), Transdisciplinarity for smallscale fisheries governance (pp. 75-90). Springer Nature.

Lowitt, K., Levkoe, C., Lauzon, R., Ryan, K., \& Sayers, D. (2019b). Indigenous self-determination and food sovereignty through fisheries governance in the Great Lakes Region. In P. Andrée, J. Clark, C. Levkoe, \& K. Lowitt (Eds.), Civil society and social movements in food system governance (pp. 145-163). Routledge Press.

Lowitt, K. (2013). Examining fisheries contributions to community food security: Findings from a household seafood consumption survey on the west coast of Newfoundland. Journal of Hunger and Environmental Nutrition, 8(2), 221-241. https://doi.org/10.1080/19320248.2013.786668

MacIver, K. (2016, September). Eat the fish. The Walleye Magazine, 7(9).

McCay, B. et al. (1995). Individual transfer quotas (ITQs) in Canada and U.S. fisheries. Ocean and Coastal Management, 28(1-3), 85-115.

Minnesota Sea Grant. (2014). October 23. Lake Superior's fish species. Retrieved from http://www.seagrant.umn.edu/fisheries/superior fish species

McCullough, A. B. (1989). The commercial fishery of the Canadian Great Lakes. Ottawa, Ontario: Queen's Printer.

Haggan, N., Neis, B., \& Baird., I. (2007). Fishers' knowledge in fisheries science and management. Paris, France: UNESCO Publishing.

Nelson, C.H., Bavington, D., Lowitt, K., \& Nagy, M. (2013, July). Where is the fish in the local food movement? Alternatives Journal, 39(4), 24-28. http:// www.alternativesjournal.ca/science-and-solutions/wheres-fish

Norman, E. (2015). Governing transboundary waters: Canada, the United States, and Indigenous communities. New York, NY: Routledge Ptress.

Nokiiwin Tribal Council. (n.d). Robinson Superior Treaty. Retrieved from http:// www.nokiiwin.com/robinson-superior-treaty 
Olson, J., Clay, P.M., \& Pinto da Silva, P. (2014). Putting the seafood in sustainable food systems. Marine Policy, 43, 104-111. https://doi.org/10.1016/j. marpol.2013.05.001

OMNRF. (2012-2018a). Fish management history. Retrieved from https://www. ontario.ca/page/fish-management-history

OMNRF. (2012-2018b). Provincial fish background strategy. Retrieved from https://www.ontario.ca/page/provincial-fish-strategy-background

OMNRF. (2011). Strategic policy for Ontario's commercial fisheries. Retrieved from https://www.ontario.ca/document/strategic-policy-commercial-fisheries-2011

Ontario Fisheries Regulation. (2007). Government of Canada Statutory Orders and Regulations. SOR/2007-237. Retrieved from http://laws-lois.justice. gc.ca/eng/regulations/SOR-2007-237/

Ontario Nature. (2014). Beyond the field: The value of forest and freshwater foods in Northern Ontario. Retrieved from https://ontarionature.org/wp-content/ uploads/2017/10/beyond_the_fields.pdf

Ommer, R.E., \& Paterson, B. (2014). Conclusions: Reframing the possibilities for natural and social science dialogue on the economic history of natural resources. Ecology and Society, 19(1), 17. https://doi.org/10.5751/ES-05972-190117

Parliament ofCanada.(1997).Evidence.Retrieved from http://www.ourcommons. ca/Content/Archives/Committee/352/iand/evidence/31 97-03-10/ iand31 blk-e.html

Pinkerton, E. (2013). Alternatives to ITQs in equity-efficiency-effectiveness trade-offs: How the lay-up system spread effort in the BC halibut fishery. Marine Policy, 42, 5-13. https://doi.org/10.1016/j.marpol.2013.01.010

Prinselaar, J. (2018, May). Freshwater feast. Northwest Nosh, 1.

Quimby, G. I. (1960). Indian life in the Upper Great Lakes, 11,000 BC to AD 1800. Chicago, Illinois: University of Chicago Press.

Rogers, E. S. (1972). Ojibwa fisheries in Northwestern Ontario. Toronto, Ontario: Commercial Fish and Fur Branch, Ontario Ministry of Natural Resources.

Roinila, M. (2003). Finnish commercial fishermen on Lake Superior: Rise and fall of an ethnic fishery. Middle States Geographer, 36, 25-37.

Rotondi M. A., O'Campo P., O'Brien K., et al. (2017). Our Health Counts Toronto: Using respondent-driven sampling to unmask census undercounts of an urban indigenous population in Toronto, Canada. BMJ Open 7(12). https://doi.org/10.1136/bmjopen-2017-018936 
Saugeen Ojibway Nation Territories. (2004). Saugeen Ojibway Nation Territories: Jumping to conclusions: GLFC, conflict of interest and the problem of stocking exotic salmon in the Great Lakes. A discussion paper presented by the Saugeen Ojibway Nation Territories at the IAGLR (International Association for Great Lake Research) Conference, University of Waterloo, Waterloo, Ontario.

Seto, K., \& Fiorella,K.(2017). From sea to plate: The role of fish in a sustainable diet. Frontiers in Marine Science, 4(74). https://doi.org/10.3389/fmars.2017.00074

Song, A., Chunepagdee, R., \& Jentoft, S. (2013). Values, images, and principles: What they represent and how they may improve fisheries governance. Marine Policy, 4O(C), 167-175. https://doi.org/10.1016/j.marpol.2013.01.018

Song, A.M., Temby, O., Krantzberg, G., \& Hickey, G.M. (2017). Institutional features of U.S.-Canadian transboundary fisheries governance: Organizations and networks, formal and informal. In O. Temby, \& P. Stoett (Eds.), Towards continental environmental policy? North American transnational networks and governance (pp. 156-179). Albany, NY: SUNY Press.

Spooner, E. (2014). Monterey Bay Aquarium seafood watch. Retrieved from http://seafood.ocean.org/wp-content/uploads/2016/10/Lake-Superiorlakefish.pdf

Statistics Canada. (2018). Household food insecurity, by age group and food insecurity status. Retrieved from https://www150.statcan.gc.ca/t1/tbl1/en/tv action?pid=1310046301\&pickMembers\%5B0\%5D =1.88\&pickMembers\%5 B1\%5D=3.1

Statistics Canada. (2016). Census profile, 2016 Census. Thunder Bay [Census metropolitan area], Ontario and Ontario [Province]. https://www12.statcan. gc.ca/census-recensement/2016/dp-pd/prof/details/page.cfm?Lang=E\&G eo1=CMACA\&Code1 $=595 \& G e o 2=P R \&$ Code $2=35 \& D a t a=$ Count $\&$ Sea $\underline{\mathrm{rch} T e x t=\text { thunder\%20bay } \& \text { SearchType }=\text { Begins } \& \text { SearchPR }=01 \& B 1=\text { Ethn }}$ ic\%20 rigin \&TABID $=1$

Swedish Finn Historical Society. (2009). Finnish immigration to North America \& Northeastern Minnesota. Retrieved from http://finlander.genealogia.fi/sfhswiki/ index.php/Finnish Immigration to North America \%26 Northeastern Minnesota

Tansey, G., \& Worsley, T. (1995). The food system: A guide. London: Earthscan Publications Ltd. 
Thunder Bay Food Charter. (2008). City of Thunder Bay. Retrieved from http:// www.ecosuperior.org/upload/documents/food charter sm.pdf

Thunder Bay and Area Food Strategy. (2018). Retrieved from http://tbfoodstrategy. $\underline{\mathrm{com} /}$

Thunder Bay and Area Food Strategy. (2015). Community food security report card. Retrieved from http://tbfoodstrategy.ca/files/9614/5804/8867/ FoodStrategy FoodSecurityReportCard WEB.pdf

Wiber, M., Berkes, F., Charles, A., \& Kearney, J. (2014). Participatory research supporting community-based fishery management. Marine Policy, 28(6), 459-468. https://doi.org/10.1016/j.marpol.2003.10.020

Wightman, W.R., \& Wightman, N.M. (1997). The land between: Northwestern Ontario resource development, 1800 to the 1990s. Toronto: University of Toronto Press.

\section{Acknowledgements}

We sincerely thank all the participants who shared their time to contribute their knowledge and experience. We also thank Vikki Schembri, Veronica Charette, and Ambili Kariaparambil Rajan for research support. Lastly, we greatly acknowledge conceptual input from the Food: Locally Embedded Globally Engaged (FLEdGE) research team, and financial support from the Social Sciences and Humanities Research Council of Canada.

\section{Authors}

Kristen Lowitt is assistant professor in the Department of Geography and Environment at Brandon University in Brandon, Manitoba.

Charles Z. Levkoe is associate professor, director of the Sustainable Food Systems Lab, and Canada Research Chair in Sustainable Food Systems at Lakehead University in Thunder Bay, Ontario.

Connie Nelson is professor emeritus in the School of Social Work at Lakehead University in Thunder Bay, Ontario. 